\title{
THE EXPERIMENTAL VALIDATION OF THE GROUNDING DEVICE RESISTANCE MEASUREMENT METHOD
}

Purpose. The paper considers experimental research of three-electrode units for measuring the resistance of grounding devices for different purposes. Methodology. The experimental study of the method of resistance measurement of grounding devices for any design in any soil structure using the method of physical modeling is presented. Results. By results of model operation the set of equations of the sixth order is solved. It allowed to determine the own and mutual impedance in the three-electrode unit with high accuracy without searching the point of zero potential. Features of measuring and defining the own and relative resistances of various combinations of electrodes for three-electrode measuring unit are considered. Originality. The necessity of finding a zero potential point is excluded. Practical value. The proposed method provides the smallest possible spacing of potential electrodes outside the grounding devices. This reduces the wiring length measurement circuit in several times, increases the ratio "signal - noise», removes the restrictions on building of the territory outside the test grounding device. References 7 , tables 10 , figures 5 .

Key words: experimental research, grounding device, the resistance measurement method, three-electrode unit, the method of physical modeling, experimental validation.

Рассмотрены экспериментальные исследования трехэлектродной установки для измерения сопротивления заземляющих устройств различного назначения. На основе использования метода физического моделирования представлено экспериментальное обоснование метода измерения сопротивления заземляющего устройства любой конструкции в произвольной структуре грунта. По результатам моделирования решена система уравнений шестого порядка, что позволило определить собственные и взаимные сопротивления в трехэлектродной установке с достаточно высокой точностью и без отыскания точки нулевого потенциала. Библ. 7, табл. 10, рис. 5.

Ключевые слова: экспериментальные исследования, заземляющее устройство, метод измерения сопротивления, трехэлектродная установка, метод физического моделирования, экспериментальное обоснование.

Introduction and problem definition. Currently, the three-electrode measuring device for measuring the resistance of grounding devices (GD) is widespread [1]. One of the main problems to be solved to get to this setting, sufficiently accurate results, is as specified in [2], the right choice of locations of measuring electrodes, i.e. such their arrangement in which the resistance of the measured value differs from its true value by not more than $10 \%$ in either direction. However, in many cases (50\%) measuring the GD resistance for urban and industrial substations poses a serious problem to the present.

Analysis of recent investigations and publications. The problem of improving the accuracy of measurement of electrical parameters of the earth and GD are engaged many scientists both domestic and foreign.

Calculation method for determining the optimal position of the measuring electrodes in the measurement of GD resistance of large dimensions allowing to place the electrodes at short distances from the GD is described in [3]. However, it is noted that the calculations with the help of considered GD models have only limited application due to their external fields.

Analysis of Tagg methods for measurement of GD resistance given in [4] is shown that Tagg method is not suitable in soils with increasing of soil resistivity by depth.

The theoretical possibility of precise measurement of the GD resistance for each character of the soil heterogeneity and of any size and configuration of GD without the use of computer codes is noted in [5]. However, unfortunately, in this case it will be necessary to determine the location of the potential electrode by finding the point of zero potential on-site measurements.

Mathematical modeling of the process of GD resistance measurement current of industrial frequency in multilayer soil is presented in [6] which describes an algorithm for calculating measurement errors at different locations of the measuring electrodes and an example of the construction of lines of equal errors for GD of complex shapes in a four ground. Unfortunately, as the authors note [6], choose a layout of electrodes, in which the measured GD resistance equals true, experimentally in measurements on the ground impossible.

In [7] the author provides a theoretical basis of a new method of GD resistance measurement with a threeelectrode measuring setup with any character of soil heterogeneity, of any size and configuration of GD and the arbitrary placement of the measurement electrodes without finding the point of zero potential.

The goal of the work is the experimental validation of the method [7] for measurement of GD resistance by means of a three-electrode measuring unit without finding a point of zero potential.

Experimental technique. For the study models of GD in the form of discs of different diameters $d 1=10$ $\mathrm{cm}, d 2=5 \mathrm{~cm}, d 3=9 \mathrm{~cm}$ were accepted. The locations of GD in the electrolytic bath are shown in Fig. 1 and did not change in all experiments. The minimum distance between the edges of GD were $a=b=c=1 \mathrm{~cm}$. Several series of experiments were performed.

(C) I.V. Nizhevskyi, V.I. Nizhevskyi, V.E. Bondarenko 


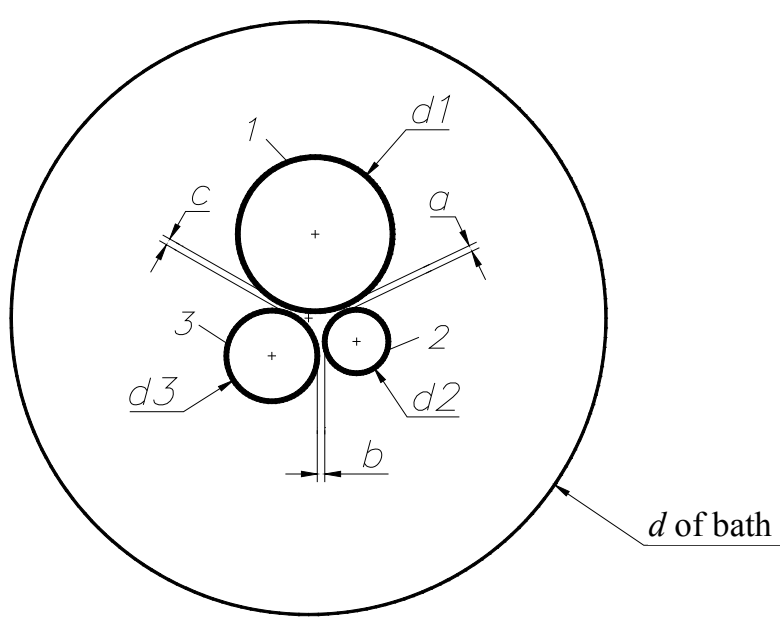

Fig. 1. Location of GD on the water surface in the electrolytic bath (plan view)

In the first series measurements of flowing from the GD current $\left(I_{10}, I_{20}, I_{30}\right)$ and voltage $\left(U_{10}, U_{20}, U_{30}\right)$ were performed to determine the internal resistance of GD, i.e. of each in its place in the absence of the others as shown in Fig. 2 for GD 1 and dashed to GD 2 and 3. The results of measurements and calculations of own GD $\left(R_{10}, R_{20}\right.$ и $R_{30}$ ) resistances are presented in Table 1 .

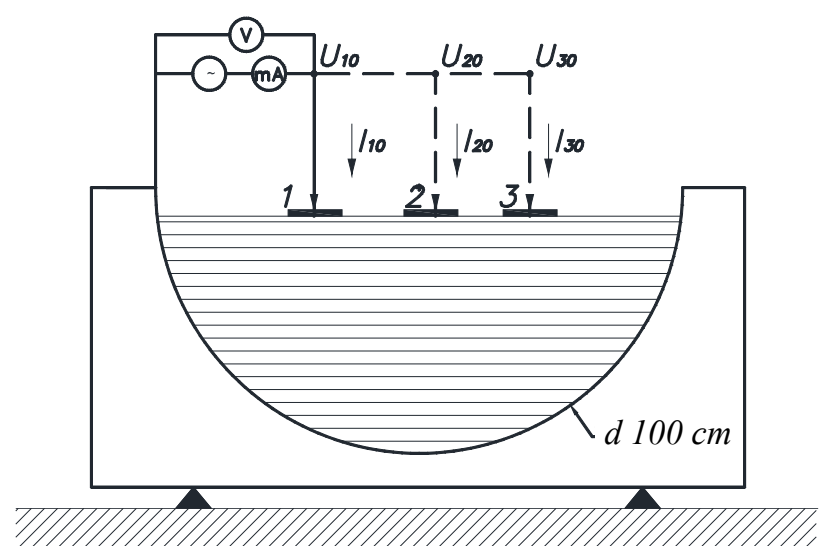

Fig. 2. Schematic layout of GD in the electrolytic bath (sectional view) and connection of devices for measurements

Table 1

Results of measurements and calculations of own GD resistances

\begin{tabular}{|c|c|c|c|c|c|c|c|c|c|}
\hline GD No. & \multicolumn{3}{|c|}{1} & \multicolumn{3}{c|}{2} & \multicolumn{3}{c|}{3} \\
\hline $\begin{array}{c}\text { Measured } \\
\text { parameter }\end{array}$ & $\begin{array}{c}I_{10}, \\
\mathrm{~mA}\end{array}$ & $\begin{array}{c}U_{10}, \\
\mathrm{~V}\end{array}$ & $\begin{array}{c}R_{10}, \\
\Omega\end{array}$ & $\begin{array}{c}I_{20}, \\
\mathrm{~mA}\end{array}$ & $\begin{array}{c}U_{20}, \\
\mathrm{~V}\end{array}$ & $\begin{array}{c}R_{20}, \\
\Omega\end{array}$ & $\begin{array}{c}I_{30}, \\
\mathrm{~mA}\end{array}$ & $\begin{array}{c}U_{30}, \\
\mathrm{~V}\end{array}$ & $\begin{array}{c}R_{30}, \\
\Omega\end{array}$ \\
\hline $\begin{array}{c}\text { Parameter } \\
\text { value }\end{array}$ & 159 & 8.63 & 54.28 & 84 & 8.8 & 104.76 & 146 & 8.65 & 59.246 \\
\hline
\end{tabular}

The second series of experiments was carried out using the three GD. In this case, a source connected to the earth electrode 1 and the bath body, i.e., current is injected into the first GD. We conducted $I_{10}$ current measuring circuit, the voltage on the grounding conductors 1,2 and 3 with respect to the bath housing $\left(U_{10}, U_{20}, U_{30}\right)$, the voltage between grounding 1 and $2\left(U_{12}\right)$, GD between 1 and $3\left(U_{13}\right)$, and the GD 2 and $3\left(U_{23}\right)$ in the circuit shown in Fig. 3.

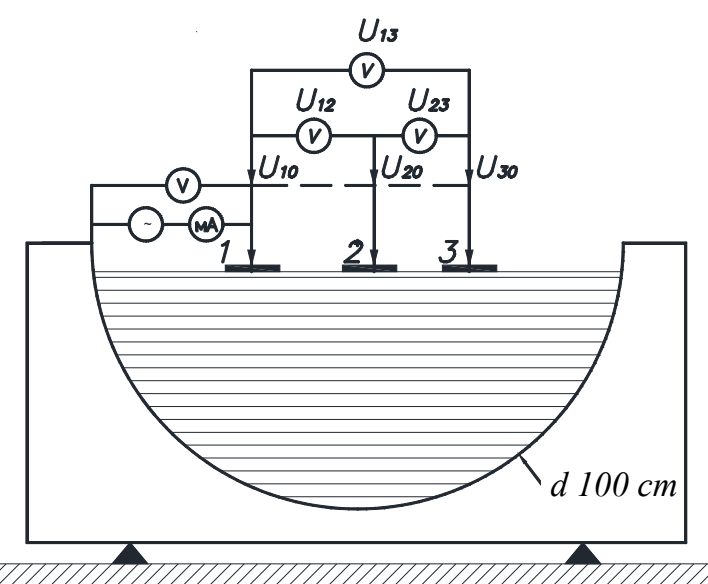

Fig. 3. Schematic layout of GD in the electrolytic bath (sectional view) and connection of devices for measurements

Similar measurements were made for cases source connection between the bath housing and the GD 2, and then GD 3. The results are shown in Table 2.

Table 2

Results of measurements at the source connection between the bath body and GD

\begin{tabular}{|c|c|c|c|c|c|}
\hline \multicolumn{2}{|c|}{$\begin{array}{c}\text { Source input } \\
\text { into GD 1 }\end{array}$} & \multicolumn{2}{c|}{$\begin{array}{c}\text { Source input } \\
\text { into GD 2 }\end{array}$} & \multicolumn{2}{c|}{$\begin{array}{c}\text { Source input } \\
\text { into GD 3 }\end{array}$} \\
\hline $\begin{array}{c}\text { Measured } \\
\text { parameter }\end{array}$ & $\begin{array}{c}\text { Parameter } \\
\text { value }\end{array}$ & $\begin{array}{c}\text { Measured } \\
\text { parameter }\end{array}$ & $\begin{array}{c}\text { Parameter } \\
\text { value }\end{array}$ & $\begin{array}{c}\text { Measured } \\
\text { parameter }\end{array}$ & $\begin{array}{c}\text { Parameter } \\
\text { value }\end{array}$ \\
\hline$I_{10}, \mathrm{~mA}$ & 159.4 & $I_{20}, \mathrm{~mA}$ & 82.1 & $I_{30}, \mathrm{~mA}$ & 137.2 \\
\hline$U_{10}, \mathrm{~V}$ & 8.7 & $U_{20}, \mathrm{~V}$ & 8.89 & $U_{30}, \mathrm{~V}$ & 8.75 \\
\hline$U_{12}, \mathrm{~V}$ & 7.7 & $U_{12}, \mathrm{~V}$ & 8.4 & $U_{12}, \mathrm{~V}$ & 0.3 \\
\hline$U_{13}, \mathrm{~V}$ & 7.9 & $U_{13}, \mathrm{~V}$ & 0.01 & $U_{13}, \mathrm{~V}$ & 7.7 \\
\hline$U_{23}, \mathrm{~V}$ & 0.2 & $U_{23}, \mathrm{~V}$ & 8.4 & $U_{23}, \mathrm{~V}$ & 7.4 \\
\hline
\end{tabular}

Then, studies were carried out in the third series with three GD without their connection with the bath. In this case the source is introduced between GD 1 and 2 as shown in Fig. 4. In this case, measured flowing in the current circuit $I_{12}$ and the voltage between GD 1 and 2 $\left(U_{12}\right)$, between GD 1 and $3(U 13)$, between 2 and $3\left(U_{23}\right)$, and the voltage between each GD (1,2 or 3$)$ and the wall (casing) of bath, i.e. $U_{10}, U_{20}$ and $U_{30}$ as shown in Fig. 4 for GD 3.

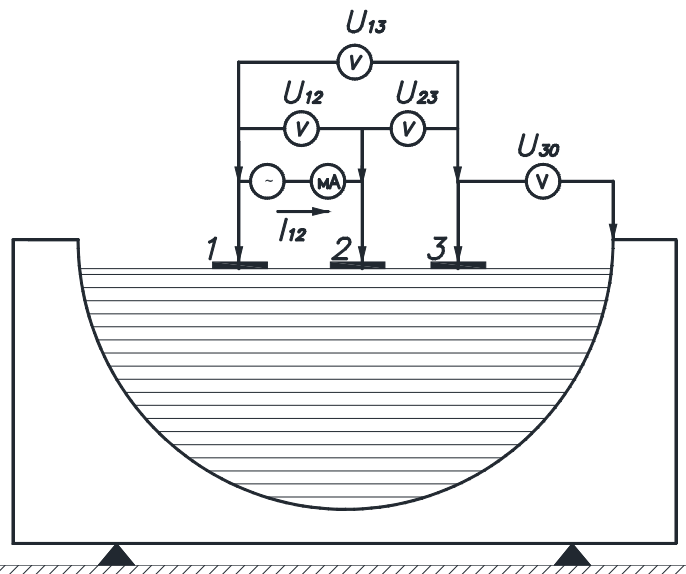

Fig. 4. Measurement circuit for three GD without their connection with bath housing 
Similar measurements were made while entering the source between GD 2 and 3, and between GD 1 and 3 . The results of these measurements are presented in Table 3.

Table 3

Results of measurements of GD parameters without source connection with bath housing

\begin{tabular}{|c|c|c|c|}
\hline $\begin{array}{c}\text { Measured } \\
\text { parameter }\end{array}$ & $\begin{array}{c}\text { Source entering } \\
\text { between } \\
\text { GD 1 and 2 }\end{array}$ & $\begin{array}{c}\text { Source entering } \\
\text { between } \\
\text { GD 1 and 3 }\end{array}$ & $\begin{array}{c}\text { Source entering } \\
\text { between } \\
\text { GD 2 and 3 }\end{array}$ \\
\hline$I_{12}, \mathrm{~mA}$ & 70.4 & - & - \\
\hline$I_{13}, \mathrm{~mA}$ & - & 103.6 & - \\
\hline$I_{23}, \mathrm{~mA}$ & - & - & 70.1 \\
\hline$U_{12}, \mathrm{~V}$ & 8.97 & 4.175 & 5.447 \\
\hline$U_{13}, \mathrm{~V}$ & 3.27 & 8.65 & 3.05 \\
\hline$U_{23}, \mathrm{~V}$ & 5.7 & 4.475 & 8.5 \\
\hline$U_{10}, \mathrm{~V}$ & 2.34 & 3.58 & 0.65 \\
\hline$U_{20}, \mathrm{~V}$ & 6.62 & 0.6 & 6.1 \\
\hline$U_{30}, \mathrm{~V}$ & 0.94 & 5.1 & 2.4 \\
\hline
\end{tabular}

In the fourth series of experiments, measurements were made with two GD, i.e., in the absence of the third one and without their connection with bath housing. Sources include grounding between 1 and 2, as shown in Fig. 5. In this case, we measured flowing in the current circuit $\left(I_{12}\right)$, the voltage between the GD 1 and $2\left(U_{12}\right)$ and the voltage between the bath housing and GD $1\left(U_{10}\right)$, and between the bath housing and the GD $2\left(U_{20}\right)$.

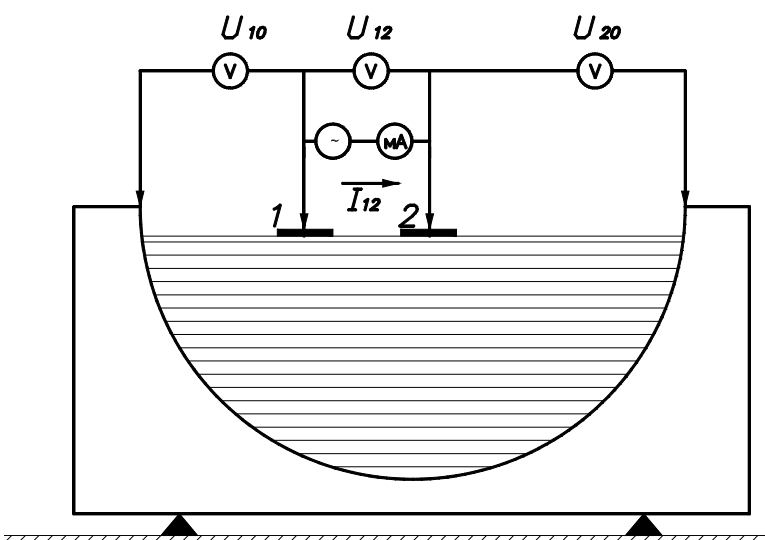

Fig. 5. Measurement circuit for two GD without their connection with bath housing

Similar measurements were made and when the source is turned on between the GD 1 and 3, and between the GD 2 and 3. The measurement results are shown in Table. 4.

Comparative analysis of the results of physical modeling of three-piece group of GD and the results of determination by the developed method of measuring own and mutual resistances of GD. According to the results of experiments for the measurements of earth models derived parameters that are given in the Table 5 . In this case, the definition of resistivity of the medium gives $\rho=12 \Omega \cdot \mathrm{m}$, i.e. $\Delta R=3.8 \Omega$ - the amendment to the final dimensions of the bath as determined by the formula for the hemisphere.
Results of measurements for two GD without their connection with bath housing

\begin{tabular}{|c|c|c|c|}
\hline $\begin{array}{c}\text { Measured } \\
\text { parameter }\end{array}$ & $\begin{array}{c}\text { Source entering } \\
\text { between } \\
\text { GD 1 and 2 }\end{array}$ & $\begin{array}{c}\text { Source entering } \\
\text { between } \\
\text { GD 1 and 3 }\end{array}$ & $\begin{array}{c}\text { Source entering } \\
\text { between } \\
\text { GD 2 and 3 }\end{array}$ \\
\hline$I_{12}, \mathrm{~mA}$ & 71.6 & - & - \\
\hline$I_{13}, \mathrm{~mA}$ & - & 105.3 & - \\
\hline$I_{23}, \mathrm{~mA}$ & - & - & 69.8 \\
\hline$U_{12}, \mathrm{~V}$ & 8.9 & - & - \\
\hline$U_{13}, \mathrm{~V}$ & - & 8.8 & - \\
\hline$U_{23}, \mathrm{~V}$ & - & - & 8.8 \\
\hline$U_{10}, \mathrm{~V}$ & 2.4 & 3.7 & - \\
\hline$U_{20}, \mathrm{~V}$ & 6.5 & - & 6 \\
\hline$U_{30}, \mathrm{~V}$ & - & 5.1 & 2.8 \\
\hline
\end{tabular}

Table 5

Results of assessment of GD own resistances

\begin{tabular}{|c|c|c|c|}
\hline \multirow{2}{*}{ Determined parameter } & \multicolumn{3}{|c|}{ Own resistances, $\Omega$} \\
\cline { 2 - 4 } & $R_{1}$ & $R_{2}$ & $R_{3}$ \\
\hline By Table 1 & 54.28 & 104.76 & 59.246 \\
\hline Taking into account $\Delta R$ & 58.08 & 108.56 & 63.046 \\
\hline
\end{tabular}

The measurement results shown in Table 4 can determine the input resistance at the input source between GD, for example as 1 and 2, by the expression

$$
R_{12 \text { inp }}=U_{12} / I_{12}=8.9 / 0.0716=124.3 \Omega \text {. }
$$

Similarly we obtain $R_{13 \text { inp }}$ and $R_{23 \text { inp. }}$. Results are presented in Table 6.

Table 6

Results of assessment of GD input resistances for two GD without their connection with bath

\begin{tabular}{|c|c|c|c|}
\hline \multirow{2}{*}{$\begin{array}{c}\text { Determined } \\
\text { parameter }\end{array}$} & \multicolumn{3}{|c|}{ Input resistances between GD, $\Omega$} \\
\cline { 2 - 4 } & $R_{12 \text { inp }}$ & $R_{13 \text { inp }}$ & $R_{23 \text { inp }}$ \\
\hline Parameter value & 124.3 & 83.6 & 126 \\
\hline
\end{tabular}

The obtained results for the input resistances (see Table 6) make it possible to determine the approximate values their own resistances of separate GD as follows. Measurements performed for the respective pairs of GD, i.e., input resistance between the GD (Table 6) allow us to write the following equations

$$
\begin{aligned}
& R_{1}+R_{2}-2 R_{12}=R_{12 \mathrm{inp}} \\
& R_{1}+R_{3}-2 R_{13}=R_{13 \mathrm{inp}} \\
& R_{2}+R_{3}-2 R_{23}=R_{23 \mathrm{inp}}
\end{aligned}
$$

Neglecting (assumption) mutual resistances $\left(R_{12}, R_{13}\right.$ and $R_{23}$ ) within a couple and the influence of the third electrode we obtain a system of three equations with three unknowns. We carry out solution to this system, and the results of calculations of its own approximate values of GD resistances are summarized in Table 7.

Table 7

Approximate values of own GD resistances

\begin{tabular}{|c|c|c|c|}
\hline \multirow{2}{*}{ Approximate values of own GD resistances } \\
\hline \multirow{2}{*}{ Determined parameter } & \multicolumn{3}{|c|}{ Own resistances, $\Omega$} \\
\cline { 2 - 4 } & $R_{1}$ & $R_{2}$ & $R_{3}$ \\
\hline Parameter value & 40.95 & 83.35 & 42.65 \\
\hline
\end{tabular}

We calculate approximate values of the mutual resistances of the corresponding pairs of GD based on the fact 
that the mutual resistance of two interacting GD resistance is always less than the least of them. [4] On the basis of the relation (1):

$$
\begin{gathered}
R_{12 \mathrm{mut}}=\left(R_{1}+R_{2}-R_{12 \mathrm{inp}}\right) / 2= \\
=(58.08+108.56-124.3) / 2=21.17 \Omega .
\end{gathered}
$$

Similarly we obtain mutual resistances $R_{13 \mathrm{mut}}$ and $R_{23 \text { mut }}$ and summarize results in Table 8 .

Table 8

Assessment of mutual resistances between corresponding GD couples

\begin{tabular}{|c|c|c|c|}
\hline \multirow{2}{*}{ Determined parameter } & \multicolumn{3}{|c|}{ Mutual resistances between GD, $\Omega$} \\
\cline { 2 - 4 } & $R_{12 \mathrm{mut}}$ & $R_{13 \mathrm{mut}}$ & $R_{23 \mathrm{mut}}$ \\
\hline Parameter value & 21.17 & 18.79 & 22.8 \\
\hline
\end{tabular}

The obtained approximate values of circuit parameters (see Table 7 and Table 8) according to the procedure described in [7] we input as initial values for the solutions of the system of six equations with six unknowns in which the right sides are represented by measurements shown in Table 3 as follows.

The results of voltages $U_{13}$ and $U_{23}$ and current $I_{12}$ measurements at the input of the source between GD 1 and 2 allow to obtain input resistances:

$$
\begin{gathered}
R_{13 \mathrm{~A}}=U_{13} / I_{12}=46.45 \Omega ; \\
R_{32 \mathrm{~A}}=U_{23} / I_{12}=81.1 \Omega .
\end{gathered}
$$

Results of similar calculations for input of the source between GD 2 and 3, as well as D 1 and 3 are shown in Table 9.

Table 9

Results of assessment of input resistances at the input of the source between corresponding GD

\begin{tabular}{|l|c|c|c|c|c|c|}
\hline \multicolumn{1}{|c|}{$\begin{array}{c}\text { Source } \\
\text { connection }\end{array}$} & \multicolumn{2}{|c|}{$\begin{array}{c}\text { Between GD 1 } \\
\text { and 2 }\end{array}$} & $\begin{array}{c}\text { Between GD } \\
1 \text { and 3 }\end{array}$ & \multicolumn{2}{c|}{$\begin{array}{c}\text { Between GD 2 } \\
\text { and 3 }\end{array}$} \\
\hline $\begin{array}{l}\text { Determined } \\
\text { parameter }\end{array}$ & $R_{13 \mathrm{~A}}$ & $R_{32 \mathrm{~A}}$ & $R_{12 \mathrm{~B}}$ & $R_{32 \mathrm{~B}}$ & $R_{12 \mathrm{C}}$ & $R_{13 \mathrm{C}}$ \\
\hline $\begin{array}{l}\text { Parameter } \\
\text { value, } \Omega\end{array}$ & 46.45 & 81.1 & 40.3 & 43.2 & 77.7 & 43.599 \\
\hline
\end{tabular}

Results of solving the system of equations [7] by developed by the author program in MathCad packet are summarized in Table. 10.

Table 10 Assessment of discrepancies between calculated and experimental values of own and mutual GD resistances

\begin{tabular}{|c|c|c|c|c|c|c|}
\hline Parameter, $\Omega$ & $R_{1}$ & $R_{2}$ & $R_{3}$ & $R_{12}$ & $R_{13}$ & $R_{23}$ \\
\hline Initial value & 40.95 & 83.35 & 42.65 & 21.17 & 18.79 & 22.8 \\
\hline Calculation & 60.42 & 98.43 & 62.39 & 20.62 & 17.56 & 22.74 \\
\hline Experiment & 58.08 & 108.56 & 63.046 & 21.17 & 18.79 & 22.8 \\
\hline Discrepancy, \% & 4.04 & 9.33 & 1.03 & 2.57 & 6.5 & 0.2 \\
\hline
\end{tabular}

Analyzing the data in Table 10 we conclude that the results of the calculations are in good agreement with the results of measurements obtained in the experiments. The discrepancy does not exceed $10 \%$ which is a good result with acceptable error.

It should be noted that during the time of measurement, as the voltage source has been applied, the voltage change occurred almost negligible and can be neglected.
However, due to the processes taking place at the surface of the electrodes when the current flows the current change occurred more noticeable. This affects the results which are shown in Table 9 and Table 4, and it should be excluded.

Obviously, this can be attributed to the resulting discrepancy between calculated and experimental results. In the real world measurements, these differences should be significantly less. In all cases possible real conditions discrepancy can expect less than $10 \%$.

It should also be emphasized that the definition of the own and mutual GD resistances as the initial values was performed and the results of measurements in the three-element system (Table 3). The values obtained for GD own and mutual resistances have a slight difference from the similar values obtained for the respective pairs of GD in the absence of a third grounding (Table 4). Substitution of these values as the initial program for calculating own and mutual resistances of GD gives the same result as in Table 10. This important factor must be used when performing on-site measurements.

\section{Conclusions.}

Firstly experimental investigation in the electrolytic bath at the NTU «KhPI» of a three-electrode unit for measuring the resistance of grounding devices for different purposes is carried out

On the basis of the method of physical modeling experimental validation of the method of resistance measurement of grounding devices of any design in any soil structure is presented.

By simulation results the system of the sixth-order equations is solved that allowed to determine own and mutual resistances in three-electrode unit with high accuracy and without finding a point of zero potential.

The proposed method provides the smallest possible spacing of the measuring electrodes outside the grounding devices. This is several times reduces the length of the connecting wires of the measuring circuit increases the ratio «signal - noise», removes the restrictions on the development of the territory outside the tested grounding device.

The obtained results showed that developed in [7] method provides fairly accurate results in all cases of measurements of resistance of grounding devices of electrical equipment.

\section{REFERENCES}

1. SOU 31.2-21677681-19:2009. Viprobuvannya ta kontrol' pristroyiv zazemlennya elektroustanovok. Tipova instruktsiya [SOU 31.2-21677681-19:2009. Test and control devices, electrical grounding. Standard instruction.]. Kyiv, Minenergovugillya Ukrayiny Publ., 2010. 54 p. (Ukr).

2. Burgsdorf V.V., Yakobs A.I. Zazemlyayushchie ustroystva elektroustanovok [Grounding device of electrical installations]. Moscow, Energoatomizdat Publ., 1987. 400 p. (Rus).

3. Oslon A.B., Kostruba S.I. Measuring the resistance of large grounding devices. Electrichestvo, 2006, no.8. pp. 49-56. (Rus).

4. Oslon A.B. Tagg methods analysis for measuring grounding resistance. III Rossiiskaia konferentsiia po zazemliaiushchim ustroistvam: Sbornik dokladov [3rd Russian Conf. on Grounding Devices: Collected Papers]. Novosibirsk, Russia, 27-31 October 2008, pp. 111-120. (Rus).

5. Oslon A.B., Tselebrovskii Iu.V. The intersection of the potential curves and the resistance of the grounding device III Ros- 
siiskaia konferentsiia po zazemliaiushchim ustroistvam: Sbornik dokladov [3rd Russian Conf. on Grounding Devices: Collected Papers]. Novosibirsk, Russia, 27-31 October 2008, pp. 121-130. (Rus).

6. Oslon A.B., Kostruba S.I. Mathematical modeling of the process of grounding resistance measurement current of industrial frequency in multilayer soil. Electrichestvo, 2008, no.5, pp. 12-17. (Rus)

7. Nizhevskyi I.V., Nizhevskyi V.I. A technique of measuring of resistance of a grounding device. Electrical engineering \& electromechanics, 2016, no.3, pp. 50-57. (Rus). doi: 10.20998/2074-272X.2016.3.08.
I.V. Nizhevskyi ${ }^{1}$, Engineer,

V.I. Nizhevskyi ${ }^{1}$, Candidate of Technical Science, Associate Professor,

V.E. Bondarenko ${ }^{1}$, Doctor of Technical Science, Professor,

${ }^{1}$ National Technical University «Kharkiv Polytechnic Institute», 21, Kyrpychova Str., Kharkiv, 61002, Ukraine, phone +38 0577076977 ,

e-mail: victornizhevski@gmail.com

Received 01.09.2016

How to cite this article:

Nizhevskyi I.V., Nizhevskyi V.I., Bondarenko V.E. The experimental validation of the grounding device resistance measurement method. Electrical engineering \& electromechanics, 2016, no.6, pp. 60-64. doi: 10.20998/2074272X.2016.6.10. 